\title{
Seed removal of Araucaria angustifolia by native and invasive mammals in protected areas of Atlantic Forest
}

\author{
Clarissa Rosa $^{1,2}$, Carla Grasiele Zanin Hegel ${ }^{3 *(1)}$ \& Marcelo Passamani ${ }^{1(0)}$ \\ ${ }^{1}$ Universidade Federal de Lavras, Departamento de Biologia, Laboratório de Ecologia e Conservação de \\ Mamíferos, Setor de Ecologia, Lavras, MG, Brasil. \\ ${ }^{2}$ Instituto Nacional de Pesquisas da Amazônia, Coordenação de Biodiversidade, Manaus, AM, Brasil. \\ ${ }^{3}$ Universidade de Brasília, Campus Darcy Ribeiro, Programa de Pós-graduação em Ecologia, IB, Brasília, DF, \\ Brasil. \\ *Corresponding author: Carla Grasiele Zanin Hegel, e-mail: carlinhahehe@yahoo.com.br
}

ROSA, C.A., HEGEL, CARLA G.Z., PASSAMANI, M. Seed removal of Araucaria angustifolia by native and invasive mammals in protected areas of Atlantic Forest. Biota Neotropica 21(1): e20201111. https://doi. org/10.1590/1676-0611-BN-2020-1111

\begin{abstract}
Araucaria Forest is one of the most threatened tropical forests in the world. Wild pig (Sus scrofa) are invasive pig that is expanding through these forests and seed removing that would be available to native fauna. Our aim was to evaluate the rates of seed Araucaria (Araucaria angustifolia) removal by both small, medium, and large mammals in areas with and without wild pig. We conducted a seed-removal experiment with three treatments differing in mammals' access to seeds, in areas with and without the occurrence of wild pig. Similar numbers of seeds Araucaria were removed by small, medium and large mammals, even in areas with wild pig. However, we verified that seed removal by small mammals is graduate over time, while large mammals, especially wild pig, remove in one event. So, we recommend long-term studies to investigate competition between wild pig and native biota and the effects of wild pig on seed dispersal and seed survival.
\end{abstract}

Keywords: Brazilian Atlantic Forest; Araucaria; Rodents; Wild boar; Feral pigs.

\section{Remoção de sementes de Araucaria angustifolia por mamíferos nativos e invasores em áreas protegidas da Mata Atlântica}

Resumo: A floresta de Araucárias é uma das florestas tropicais mais ameaçadas do mundo. O javali (Sus scrofa) é um porco invasor que está se expandindo por essas florestas e removendo sementes que estariam disponíveis para a fauna nativa. Nosso objetivo foi avaliar as taxas de remoção das sementes do pinheiro brasileiro (Araucaria angustifolia) por pequenos, médios e grandes mamíferos, em áreas com e sem javali. Realizamos um experimento de remoção de sementes com três tratamentos diferentes que limitam o acesso das espécies de mamíferos às sementes do pinheiro brasileiro, em áreas com e sem a ocorrência de javalis. Números semelhantes de sementes de pinheiro brasileiro foram removidos por pequenos, médios e grandes mamíferos, mesmo em áreas com javalis. No entanto, verificamos que a remoção de sementes por pequenos mamíferos é gradativa ao longo do tempo, enquanto que grandes mamíferos, especialmente os javalis, removem as sementes em uma única visita. Portanto, recomendamos estudos de longo prazo para investigar a competição entre javalis e biota nativa e os efeitos dos javalis na dispersão e sobrevivência das sementes do pinheiro brasileiro.

Palavras-chave: Mata Atlântica; Pinheiro brasileiro; Roedores; Javalis; Porco Asselvajado. 


\section{Introduction}

Seed removal by animals is a key process determining the spatial structure of plant populations (Schupp 1988, Wang \& Smith 2012) and there is a tendency towards increased seed removal in areas with greater abundance of seed removers and higher plant density (Janzen 1970, 1971). In neotropics, large granivores such the white-lipped peccary Tayassu pecari are capable of changing the structure of keystone-tree populations through predation on seeds that change the quantity and distribution of seedlings (Silman et al. 2003). In tropical forests, the presence of such large granivores can maintain higher rodent assemblage diversity by suppressing the populations of dominant rodents via resource competition (Galetti et al. 2015a). This reduces the removal of seeds by small granivores because dominant rodent species are the main removers of keystone-tree seeds (Fleury \& Galetti 2006, Galetti et al. 2001, Galetti et al. 2015b).

Araucaria Forest is one of the most threatened tropical forests (Lacerda 2016, Rezende et al. 2018, Ribeiro et al. 2009) and is characterized by Araucaria trees (Araucariaceae: Araucaria angustifolia). Due to its restricted distribution, habitat fragmentation, logging, and loss of seed dispersers (Fragoso et al. 2011, Veloso et al. 1992), Araucaria populations are declining (Thomas 2013). The seed cones begin to mature two years after pollination, and development from the primitive carpel to seed takes about four years. Trees begin to set seeds between 12 and 15 years of age (Bittencourt 2007, Thomas 2013) that are dispersed from March to June by both gravity and animals (Mantovani et al. 2004). The species has large seeds (6.5 to $7 \mathrm{~g}$ ) that are produced in great abundance at a predictable time of relative scarcity of food resources in the Araucaria Forest (Mantovani et al. 2004, Souza et al. 2010). Highly nutritive (average $7 \mathrm{~g}$ and $14.8 \mathrm{kcal}$ per seed), the Araucaria seeds is considered a key resource for insects, birds, and mammals in the Araucaria Forest (Brocardo et al. 2018, Iob \& Vieira 2008, Ribeiro \& Vieira 2014).

Beside the historical deforestation, logging and poaching (Brocardo 2017), Araucaria forest have been faced a new enemy, the biological invasion of wild pig (Sus scrofa) (Rosa et al. 2017). The wild pig is native to Eurasia and northeast Africa, and is one of the most widespread invasive mammals in the world (Clout \& Russell 2007). They are recognized as an important alien ecosystem engineers with high ecological plasticity, changing the soil, vegetation cover and seed bank structure (Barrios-Garcia \& Ballari 2012, Cuevas et al. 2012, Ickes et al. 2001, Webber et al. 2010), and competing with native fauna for resources (Hegel et al. 2019, Sanguinetti \& Kitzberger 2010). The range of the wild pig is expanding throughout tropical forests (Clout \& Russell 2007, Rosa et al. 2017), where they are mainly recognized as seed removers, although they may eventually also act as dispersers (Sanguinetti \& Kitzberger 2010, Pedrosa et al. 2019).

The wild pig spread through the Araucaria Forest domain (Rosa et al. 2017) and is consuming seeds of the Araucaria (Deberdt \& Scherer 2007, Hegel \& Marini 2013, Rosa 2018). However, the effects of this invasion on the removal of Araucaria seeds or the interaction with native removers is still unknown. In addition, the previously studies evaluating seed removal of Araucaria where conducted in areas where large granivores were extinct or have their population dramatically reduced (Iob \& Vieira 2008, Ribeiro \&Vieira 2014, Vieira et al. 2011). We thus conducted a block experiment that limited the access of Araucaria seeds by mammals to identify seed removers and evaluate the rates of seed removal of both small and large granivores in areas with wild pig (and without white-lipped peccary) and areas without wild pig (and with white-lipped peccary). Beside both wild pig and white-lipped peccary are large granivores, wild pig is recognized as a highly invasive and competitive species (Massei \& Genov 2004, Barrios-Garcia \& Ballari 2012), so our hypothesis is that, in the area invaded by wild pig, the seed removal will be majoritarian executed by large mammals because of high frequency of occurrence of wild pigs in the area (Mazza et al. 2018).

\section{Material and Methods}

Our study was carried out in the Itatiaia National Park (INP) (22²6'14'N, 44³6’3'W), Brazil's first National Park created in 1937, and in the Private Natural Heritage of Alto Montana Reserve (PRNH)

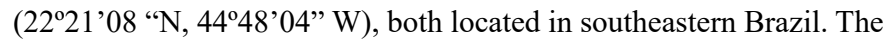
INP cover areas of Minas Gerais and Rio de Janeiro states and PRNH is located in Minas Gerais (Figure 1). The protected areas cover 28.084 (INP) and 672 (PRNH) ha of the Brazilian Atlantic Forest domain. Both are in the Serra da Mantiqueira mountain chain, which is considered to be an area of global importance for biodiversity conservation (Myers et al., 2000) and recently considered an irreplaceable protected area (Le Saout et al. 2013). The INP altitude ranges from 600 to $2791 \mathrm{~m}$ asl and our study was conducted in its lower portion, between 600 and 1600 $\mathrm{m}$ asl, which has a Cwb climate type (altitude subtropical climate), mesothermal with a rainy season in summer (Köppen 1936). The PRNH has altitude ranging from 1500 to $2500 \mathrm{~m}$ asl and has a Cfb climate type (temperate oceanic climate), mesothermal, without a dry season (Köppen 1936). The PRNH is dominated by a mixture of seasonal semideciduous montane forest and high-altitude fields characterized by the presence of the Araucaria while the lower part of INP is dominated by montane rain forest with few widely-dispersed individuals of Araucaria (Ururahy et al. 1983, Oliveira-Filho \& Fontes 2000).

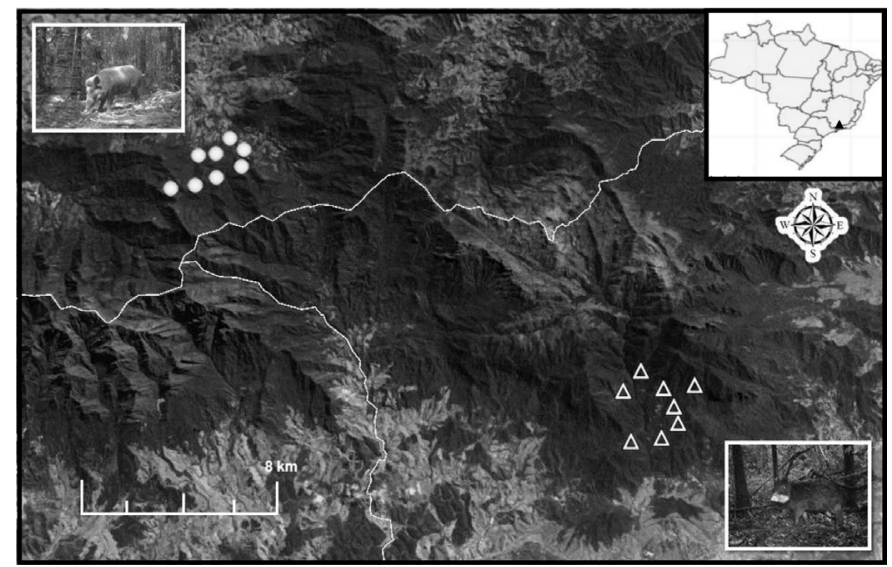

Figure 1. Study area showing the sampled points (blocks) in the area with wild pig and without white-lipped peccaries (circles), and in the area with white-lipped peccaries and without wild pig (triangles). The gray line is the division of the Brazilian states Minas Gerais, São Paulo and Rio de Janeiro.

The region of our study is distribution area of native taiassuids (Tayassu pecari - white-lipped peccaries and Pecari tajacu - collared peccary) and is suffering with wild pig' invasion since 2006 (Rosa 2018). In the PRNH occurs 21 native species of medium and large mammals (Mazza et al. 2018), while in INP occurs 22 species of native mammals 
(Aximoff et al. 2015). Wild pig occurs in all PRNH territory and is the most frequent mammal species recorded in the area (Mazza et al. 2018), however there is no evidence of its occurrence in the lower portion of INP. The white-lipped peccary is widespread in the lower portion of INP, but there is no recent record of this species in the PRNH, indicating a probable local extinction (De Abreu 2016). In this study, the INP will be referred as the area without wild pig and with white-lipped peccary, and PRNH as the area with wild pig and without white-lipped peccary.

To assess seed removal of Araucaria, we conducted an experiment from April to May 2014 during the seed harvest season, in both areas with and without wild pig. In this period, the experiment was repeated three times at intervals of 15 days. Within each area, we selected eight sampling points, around $1 \mathrm{~km}$ far from each other (Figure 1). Each point represented a block with three different treatments to segregate the species with access to seeds (Mileri et al. 2012, Ribeiro \& Vieira 2014). We collected the seeds used in the treatment in PRNH area twenty days before the study started. We arranged the treatments two meters apart, with 10 seeds in each using the same sampling design previously tested by Mileri et al. (2012). Each block had one each of the following treatments: (1) Free - seeds arranged side-by-side, forming a circle, on the ground with free access by all animals; (2) Small - seeds placed inside $75 \mathrm{~mm}$ wide and $40 \mathrm{~cm}$ length PVC pipes which were accessible only by small mammals rodents species. We secure the pipe to the ground with an iron rod to prevent medium and large mammals from rolling the pipe and access the seeds; (3) Large - seeds placed in a bowl $15 \mathrm{~cm}$ above the ground, allowing access only by medium and large mammals (see Mileri et al. 2012).

We identify seed removers placing one camera-trap in each point sampled. We used motion-activated digital cameras (Bushnell HD, ${ }^{\circ}$ Bushnell Outdoor Products, California, USA) set to take three photos every 30 seconds. The camera-traps were installed in front of experiments and were in continuous operation during the two months of data collection, resulting in 960 camera-traps/nights. Since the cameratraps run automatically over that period, we did not check them to avoid unnecessary disturbance. At the end of sampling, we recovered memory cards and identified species from the image records. We consider as seed removers those species that directly interacted with the seeds or with the pipe and bowl structures, as observed in photographic records. We also count the number of these interactions considering 1-hour interval between the photographs. We also used photographs to count frequency of occurrence of white-lipped peccary and wild pig counting all records of both species considering 1-hour apart for independent observations (Srbek-Araujo \& Chiarello 2013).

To test our hypothesis, we considered each block as a replicate and the number of seeds removed as the response variable. To evaluate how seed removal is influenced by area (with and without wild pig), treatment (Free, Small and Large) and frequency of occurrence of large granivores (white-lipped peccary and wild pig), we used Generalized Linear Mixed-effects Models (GLMM) with Poisson distribution for non-normal counting data (Bolker et al. 2008, Zuur et al. 2009). The block (i.e. sampling point) was used as random effect. We constructed models using the "glmer" function available in the "lme4" R software package (R Core Team 2017). We used the Akaike Information Criterion corrected for small samples (AICc) for model selection, to identify the variables that best explain seed removal. The best models were considered as those with $\triangle \mathrm{AICc}$ lower than 2 (Burnham \& Anderson 2002; Burnham et al. 2011).

\section{Results}

Of a total of 1440 seeds available in all treatments, $77 \%(\mathrm{~N}=1,111)$ were removed (see Appendix 1). From seeds removed, 30.2\% $(\mathrm{N}=336)$ were in the Large treatment, $34.5 \%(\mathrm{~N}=383)$ in the Free treatment and $35.3 \%(\mathrm{~N}=392)$ in the Small treatment. In the white-lipped area 552 seeds are removed, being $35 \%(\mathrm{~N}=193)$ in the Free treatment, $33 \%(\mathrm{~N}=184)$ in the Small treatment and $32 \%(\mathrm{~N}=175)$ in the Large treatment. In the wild pig area 559 seed are removed, being $37 \%(\mathrm{~N}=$ $208)$ in Small treatment, $34 \%(\mathrm{~N}=190)$ in the Free treatment and $29 \%$ $(\mathrm{N}=161)$ in the Large treatment (Figure 2 and 3). The frequency of occurrence of the wild pig was a mean of $17.87(\min =0$; $\operatorname{Max}=76)$, while white-lipped peccary has a frequency of occurrence of a mean of $39.75(\operatorname{Min}=0 ; \operatorname{Max}=175)$.

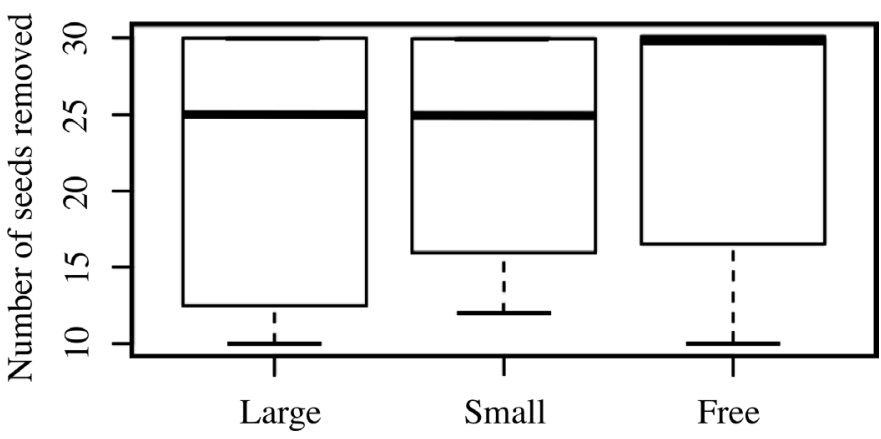

Figure 2. Seed removal in Small (seeds accessible only by small mammals), Large (seeds accessible only by medium and large mammals) or Free (seeds accessible by all mammals) treatments, in PNI area with white-lipped peccary.

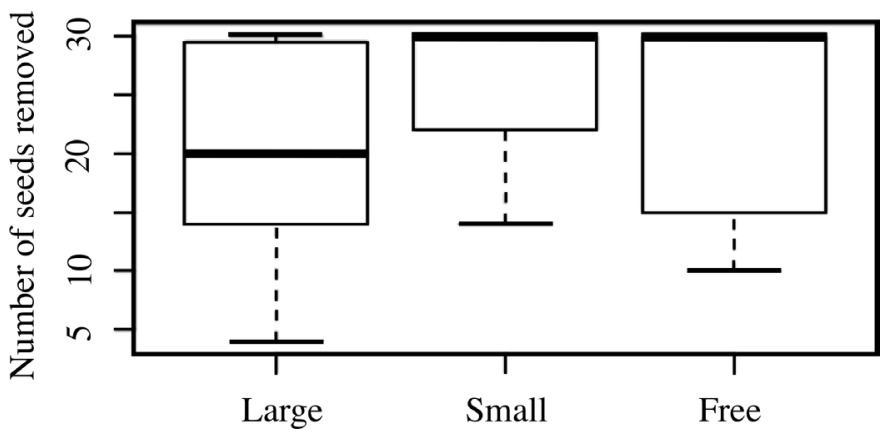

Figure 3. Seed removal in Small (seeds accessible only by small mammals), Large (seeds accessible only by medium and large mammals) or Free (seeds accessible by all mammals) treatments, in PRNH area with wild pig.

From camera-traps, we recorded 115 interactions between species removers and treatments of six taxa: wild pig $(\mathrm{N}=9)$, white-lipped peccaries $(\mathrm{N}=3)$, black-horned capuchin (Sapajus nigritus, $\mathrm{N}=$ 1), red brocket deer (Mazama americana, $\mathrm{N}=1$ ), Brazilian squirrel (Guerlinguetus ingrami, $\mathrm{N}=6$ ), dusky-legged guan (Penelope obscura, $\mathrm{N}=1)$ and small rodents $(\mathrm{N}=94)$ (see Appendix 2). We pooled all species of small rodents (except G. ingrami) into a single category because no reliable identification at species level was possible from the photographs. Although there are apparently more events of seedremoval by rodents, from camera-traps photographs we are able to 
see that those removals were gradual, with one or two seeds being removed daily, while all seed-removal events made by wild pig and white-lipped peccaries occurred in a single event by one individual. We cannot evaluate the final destination of seeds, but we found many seeds predated by both small and large mammals (see Appendix 3 ).

Treatment appears as the only variable in the best model influencing seed removal of Araucaria. The frequency of white-lipped peccary also has a positive influence in seed removal of Araucaria as shown by the third and fourth-best model (Table 1).

Table 1. Ranking of the best generalized linear mixed-effects models with poisson distribution to predict the effects of the explanatory variables on seed removal of Araucaria. Variation in AICc ( $\triangle \mathrm{AICc})$ and Akaike weight ( $\omega$ i).

\begin{tabular}{lccc}
\hline Models & AICc & $\Delta$ AICc & $\omega \mathrm{i}$ \\
\hline Treatment $(+)$ & 322.8 & 0.00 & 0.21 \\
Null model & 323.1 & 0.29 & 0.18 \\
White-lipped peccary $(+)+$ Treatment $(+)$ & 324.5 & 1.71 & 0.09 \\
White-lipped peccary $(+)$ & 324.6 & 1.78 & 0.09 \\
\hline
\end{tabular}

\section{Discussion}

Our results indicate that the amount of seed removed was influenced by experimental treatments and, different of our expectation, the frequency of occurrence of the native large granivore is more important to seed removal than the frequency of occurrence of the invasive large granivore. Even though we do not observe the presence of wild pig as determinant to seed removal of Araucaria, wild pig may be altering forest structure and the resources available for the native fauna (Sanguinetti \& Kitzberger 2010).

Large granivores in tropical forests can alter the population structure of trees, changing the quantity and distribution of seedlings through cascading effects of seed-removal rates and the distance of the seed from the parent plant; and indirectly due to competition from other seed removers (Galetti et al. 2015a, Silman et al. 2003). Although Pedrosa et al. (2019), found a positive relationship between Araucaria seeds and passage through the stomach and intestinal tract of wild pig (intact seeds in $56 \%$ of the stomachs and in $90 \%$ of the analyzed feces), we do not know the effects of the invasive population of wild pig on seedling recruitment and structure of Araucaria populations. So, it may be too early to decree this invasive species "safe" for this ecosystem, especially because wild pig have a historic of seed predation in its native distribution (Gomez et al. 2003). In addition to the consumption and destruction of Araucaria seeds in Araucaria forests, wild pig showed intense herbivory, rooting and soil overturning in areas around Araucaria trees (Hegel \& Marini 2013). This can be considered a threat to the integration and maintenance of these forests.

From a native fauna perspective, the overlap of habitat use and diet are part of the competitive interactions between wild pig and native species (Ilse \& Hellgren 1995). We could not identify competition between wild pig and native biota for seeds, but our photographic records show that small rodents gradually removed the seeds of Araucaria, returning consecutively to the experiment to feed, while large mammals (native and invasive), on the other hand, visited the experiment site, removing virtually all available seeds in one event. This occurs because species body size, species home range, and species behavior results in differences between resource sharing among rodents and large granivorous with the later needing proportionally more seeds than rodents to feel satiated (Murray 1987). So, when an invasive species like the wild pig is inserted in the trophic relations of a biological community, it can interfere with the foraging dynamics of local populations of native species, resulting in competition for resources, that was not possible to observe with our sampling design.

The history of human occupation in Araucaria forest results in a largely defaunated forest of medium and large mammals (Galetti \& Dirzo 2013, Bogoni et al. 2018). On the other hand, small rodents generally are not negatively affected by fragmentation and suffer less from hunting pressure (DeMattia et al. 2006, Pardini 2004), which results in small rodents being commonly observed as main removers of Araucaria seeds (e.g. Iob \& Vieira 2008, Solórzano-Filho 2001). Most of the Araucaria seeds removed by rodents were destroyed and less than $5 \%$ of seeds were effectively dispersed (Vieira et al. 2011, SolórzanoFilho 2001). However, the massive seed production of Araucaria in a short time (two months) (Mantovani et al. 2004) allows small rodents, especially the scatter hoarding rodents, to play a relevant role in seed dispersal of this tree (DeMattia et al. 2004, Iob \& Vieira 2008, Silman et al. 2003). In our wild pig area, the Small treatment account for most of seeds removal, which may be a reflex of the historical absence of large granivores. So, the answer we found may be related to the fact that, in eight years of invasion, wild pigs are still not participating significantly in this dynamic of seed removal, which does not mean that it will not happen. This may be because the wild pig population is not yet large enough for this effect to be noticed, especially considering that the frequency of its occurrence was half that recorded for the white-lipped peccary, or because the wild pig is using other alternative sources of food, since the PRNH region is characterized by the presence of small rural producers who report the common attack of wild pigs on crops and vegetable gardens (Pereira et al. 2019). The area of the white-lipped peccary is surrounded by urban centers and highways. That, and the fact that the white-lipped peccary is more intolerant of changes in the landscape (Keuroghlian \& Eaton 2008, Reyna-Hurtado et al. 2012), means that the species does not leave the forest and the forest's resources are the only food available to the species.

In some landscapes, especially those where the frequency of disturbances has been changed by human activities (Badano \& Cavieres 2006), exotic ecosystem engineers, such as wild pig, could eventually replace ecological functions of native ecosystem engineers that are locally extinct (see Novel Ecosystem concept in Hobbs et al. 2006 and Hobbs et al. 2009, Pedrosa et al. 2019). Thus, more studies evaluating the effects of wild pig on the final destination of seeds (i.e. seed dispersal or predation), and on seedlings and adult trees are necessary to understand the role of wild pig in recruitment of Araucaria and other tropical-forest trees. Beside removal of Araucaria seeds were the same in area with or without wild pig, the effects of wild pig may increase in the future for both Araucaria trees and native fauna, especially if no population control is undertaken, since its invasion is recent ( $<$ eight years) in our study area. Also, in Araucaria forest, the invasion of wild pig presents an opportunity to study the effects of large granivores on Araucaria populations, in localities where native large granivores are rare or extinct. In any case, we recommend long-term studies to investigate competition between wild pig and native biota and the effects of wild pig on seed dispersal and seed survival in this tropical ecosystem. 


\section{Supplementary material}

The following online material is available for this article:

Appendix 1 - Seed removal data from the three treatments of the experiment (Free, Small, and Large) in both studied protected areas [Itatiaia National Park (INP) and Private Natural Heritage of Alto Montana Reserve (PRNH)].

Appendix 2 - Seed removers of Araucaria angustifolia identified by camera-traps: Figure 1 and Figure 2. Small rodent species; Figure 3. Sapajus nigritus; Figure 4. Sus scrofa; Figure 5. Tayassu pecari.

Appendix 3 - Seeds of Araucaria angustifolia predated by A) Small rodents; B) Tayassu pecari; and C) Sus scrofa.

\section{Acknowledgements}

This article was written during the 1st Publication Workshop of the Postgraduate Program in Biodiversity, funded by the National Program for Academic Cooperation in the Amazon (PROCAD-AM/CAPES, edital No 21/2018, process No. 88887.200472 / 2018-00). We would like to thank CAPES and CNPq for fellowship to C. A. Rosa and C. G. Z. Hegel. M. Passamani was supported by a researcher fellowship from CNPq. The FAPEMIG, Tropical Forest Conservation Act and TFCA/FUNBIO for the financial resources. The ICMBio through the administration of the Parque Nacional do Itatiaia and the Instituto Alto Montana for logistical support. We thank F. H. Puertas for the field support and F. Costa and W. Magnusson for the suggestions and review of English. We thank the reviewers provided criticisms on previous drafts of the manuscript.

\section{Author Contributions}

Clarissa Rosa: Substantial contribution in the concept and design of the study; Contribution to data collection; Contribution to data analysis and interpretation; Contribution to manuscript preparation.

Carla Grasiele Zanin Hegel: Contribution to manuscript preparation; Contribution to critical revision, adding intellectual content.

Marcelo Passamani: Substantial contribution in the concept and design of the study; Contribution to critical revision, adding intellectual content.

\section{Conflicts of interest}

There is no conflict of interest.

\section{References}

Aximoff, I., Cronemberger, C. \& Pereira, F.A. 2015. Amostragem de longa duração por armadilhas fotográficas dos mamíferos terrestres em dois parques nacionais do estado do Rio de Janeiro. Oecol. Aust. 19(1):215-231.

Badano, E.I. \& Cavieres, L.A. 2006. Impacts of ecosystem engineers on community attributes: effects of cushion plants at different elevations of the Chilean Andes. Divers. Distrib. 12:388-396.

Barrios-Garcia, M. \& Ballari, A.S. 2012. Impact of Wild boar (Sus scrofa) in its introduced and native range: a review. Biol. Invasions 14:2283-2300.

Bittencourt, J.V.M. 2007. Araucaria angustifolia - its geography and ecology. $\mathrm{PhD}$ Tesis. University of Reading. Reading, Berkshire, UK.

Bogoni, J.A., Pires, J.S.R., Graipel, M.E., Peroni, N. \& Peres C.A. 2018. Wish you were here: How defaunated is the Atlantic Forest biome of its mediumto large-bodied mammal fauna? PLoS ONE 13(9): e0204515.
Bolker, B.M., Brooks, M.E., Clark, C.J., Geange, S.W., Poulsen, J. R., Stevens, M.H.H. \& White, J.S. 2009. Generalized linear mixed models: a practical guide for ecology and evolution. Trends Ecol. Evol. 24(3):127-135.

Brocardo, c.r. 2017. Defaunação e fragmentação florestal na Mata Atlântica Subtropical e suas consequências para a regeneração de Araucaria angustifolia. Tese de Doutorado. Universidade Estadual Paulista, Instituto de Biociências de Rio Claro, Rio Claro, SP. 117p.

Brocardo, c.r., Pedrosa, F. \& Galetti, M. 2018. Forest fragmentation and selective logging affect the seed survival and recruitment of a relictual conifer. For Ecol. Manag., 408:87-93.

Burnham, K.P. \& Anderson, D.R. 2002. Model Selection and Inference: A Practical Information-Theoretic. Springer-Verlag, New York.

Burnham, K.P., Anderson, D.R. \& Huyvaert, K. 2011. AIC model selection and multimodel inference in behavioral ecology: some background, observations, and comparisons. Behav. Ecol. Sociobiol. 65:23-35.

Clout, M.N. \& Russell J.C. 2007. The invasion ecology of mammals: a global perspective. Wildl. Res., 35:180-184.

Cuevas, M.F., Mastrantonio, L., Ojeda, R.A. \& Jaksic, F.M. 2012. Effects of Wild boar disturbance on vegetation and soil properties in the Monte Desert, Argentina. Mamm. Biol., 77(1):299-306.

De Abreu. 2016. Análise da ocupação do javali (Sus scrofa) no Parque Nacional do Itatiaia e entorno (Serra da Mantiqueira). Dissertação de mestrado, Programa de Pós-graduação em Ecologia Aplicada, UFLA, Lavras, MG. 53p.

Deberdt, A.J. \& Scherer, S.B. 2007. O javali asselvajado: ocorrência e manejo da espécie no Brasil. Nat. \& Conserv., 5:31-44.

DeMattia, E.A., Curran, L.M. \& Rathcke, B.J. 2004. Effects of small rodents and large mammals on neotropical seeds. Ecology, 85:2161-2170.

DeMattia, E.A., Rathcke, B. J., Curran, L.M., Aguilar, R. \& Vargas, O. 2006. Effects of small rodent and large mammal exclusion on seedling recruitment in Costa Rica. Biotropica, 38:196-202.

Fleury, M. \& Galetti, M. 2006. Forest fragment size and microhabitat effects on palm seed predation. Biol. Conserv. 131:1-13.

Fragoso, R.O., Delgado, L.E.S. \& Lopes, L.M. 2011. Aspectos da atividade de caça no Parque Nacional do Iguaçu - PR. Rev. Biol. Neotrop., 8(1):41-52.

Galetti, M., Keurophlian, A., Hanada, L. \& Morato, M.I. 2001. Frugivory and Seed Dispersal by the Lowland Tapir (Tapirus terrestris) in Southeast Brazil1. Biotropica, 33(4):723-726.

Galetti, M. \& Dirzo, R. 2013. Ecological and evolutionary consequences of living in a defaunated world. Biol. Conserv. 163:1-6.

Galetti, M., Bovendorp, R.S. \& Guevara, R. 2015a. Defaunation of large mammals leads to an increase in seed predation in the Atlantic forests. Glob. Ecol. Conserv., 3:824-830.

Galetti, M., Guevara, R., Neves, C.L., Rodarte, R.R., Bovendorp, R.S., Moreira, M., Hopkins III, J.B. \& Yeakel, J. 2015b. Defaunation affect population and diet of rodents in Neotropical rainforests. Biol. Conserv. 190:2-7.

Gomez, J.M., Garcia, D. \& Zamora, R. 2003. Impact of vertebrate acorn- and seedling-predators on a Mediterranean Quercus pyrenaica forest. For. Ecol. Manag., 180:125-134.

Hegel, C.G.Z. \& Marini, M.Â. 2013. Impact of the wild boar, Sus scrofa, on a fragment of Brazilian Atlantic Forest. Neotrop. Biol. Conserv., 8:17-24.

Hegel, C.G.Z., Santos, L.R., Marinho, J.R. \& Marini, M.Â. 2019. Is the wild pig the real "big bad wolf"? Negative effects of wild pig on Atlantic Forest mammals. Biol. Invasions, 21:3561-3574.

Hobbs, R.J., Arico, S., Aronson, J., Baron, J. S., Bridgewater, P., Cramer, V.A., Epstein, P.R., Ewel, J.J., Klink, C.A., Lugo, A.E., Norton, D., Ojima, D., Richardson, D.M., Sanderson, E.W., Valladres, F., Vilà, M., Zamora, R. \& Zobel, M. 2006. Novel ecosystems: theoretical and management aspects of the new ecological world order. Glob. Ecol. Biogeogr., 15:1-7.

Hobbs, R.J., Higgs, E., Harris, J.A. 2009. Novel ecosystems: implications for conservation and restoration. Trends Ecol. Evol., 24(11):599-605.

Ickes, K., Dewalt, S.J. \& Appanah, S. 2001. Effects of native pigs (Sus scrofa) on woody understory vegetation in a Malaysian lowland rain forest. J. Trop. Ecol., 17(1):191-206. 
Ilse, L.M. \& Hellgren, E.C. 1995. Resource partitioning in sympatric populations of collared peccaries and feral hogs in Southern Texas. J. Mammal., 76(3):784-799.

Iob, G. \& Vieira, E.M. 2008. Seed predation of Araucaria angustifolia (Araucariaceae) in the Brazilian Araucaria Forest: influence of deposition site and comparative role of small and 'large' mammals. Plant Ecol., 198:185-196.

Janzen, D.H. 1970. Herbivores and the number of tree species in tropical forests. The Am. Nat., 104(940):501-528.

Janzen, D.H. 1971. Seed predation by animals. Annu. Rev. Ecol. Syst., 2:465-492.

Keuroghlian, A. \& Eaton, D.P. 2008. Fruit availability and peccary frugivory in an isolated Atlantic Forest fragment: effects on peccary ranging behavior and habitat use. Biotropica. 40:62-70.

Köppen, W. 1936. Das geographisca System der Klimate. In W. Koppen, and R. Geiger (Eds.). Klimatologie, p. 298-312. Gebr, Borntraeger, Germany.

Lacerda, A.E.B. 2016. Conservation strategies for Araucaria Forests in Southern Brazil: assessing current and alternative approaches. Biotropica, 48(4):537544

Le Saout, S., Hoffmann, M., Shi, Y., Hughes, A., Bernard, C., Brooks, T.M., Bertzky, B., Butchart, S.H.M., Stuart, S.N., Badman, T. \& Rodrigues, A.S.L. 2013. Protected areas and effective biodiversity conservation. Science, 342(6160):803-805.

Mantovani, A., Morellato, L.P.C. \& Reis, M.S. 2004. Fenologia reprodutiva e produção de sementes em Araucaria angustifolia (Bert.) O. Kuntze. Rev. Bras. Bot., 27(4):787-796.

Massei, G. \& Genov, P.V. 2004. The environmental impact of wild boar. Galemys 16(Special edition):135-145.

Mazza, I., Rosa, C.A., Souza, A.C., Aximoff, I. \& Passamani, M. 2018. Mamíferos de médio e grande porte registrados em florestas dominadas por Araucaria angustifolia na RPPN Alto-Montana, Serra da Mantiqueira. Oecol. Aust. 22(1):74-88.

Mileri, M., Passamani, M., Eutrópio, F. \& Oliveira, A. 2012. Removal of Seeds of Exotic Jackfruit Trees (Artocarpus heterophyllus, Moraceae) in Native Forest Areas with Predominance of Jackfruit Trees in the Duas Bocas Biological Reserve, Southeastern Brazil. Int. J. Ecosyst., 2(5):93-98.

Murray, R.D. (Ed.) 1987. Seed Dispersal. Academic Press. 322p.

Myers, N., Mittermeier, R.A., Mittermeier, C.G., Fonseca, G.A.B. \& Kent, J 2000. Biodiversity hotspots for conservation priorities. Nature, 403:853-858.

Oliveira-Filho, A.T. \& Fontes, M.A.L. 2000. Patterns of floristic differentiation among Atlantic Forests in Southeastern Brazil and the influence of climate. Biotropica, 32(4b):793-810.

Pardini, R. 2004. Effects of forest fragmentation on small mammals in an Atlantic Forest landscape. Biodiv. Conserv., 13:2567-2586.

Pedrosa, F., Bercê, W., Levi, T., Pires, M. \& Galetti, M. 2019. Seed dispersal effectiveness by a large-bodied invasive species in defaunated landscapes. Biotropica, 51(6):862-873.

Pereira, C.Z., Rosa, C.A. \& Zanzini, A.C. 2019. Perception of the presence, impacts and control of the invasive species Sus scrofa in the local community living near the Itatiaia National Park, Brazil. Ethnobiology and Conservation, 8 .

R Core Team. 2017. A Language and Environment for Statistical Computing. R Foundation for Statistical Computing, Vienna, Austria. URL http:// www.R-project.org/.

Rezende, C.L., Scarano, F.R., Assad, E.D., Joly, C.A., Metzger, J.P., Strassburg, B.B.N., Tabarelli, M., Fonseca, G.A. \& Mittermeier, R.A. From hotspot to hopespot: An opportunity for the Brazilian Atlantic Forest. Perspect. Ecol. Conserv., 16(4):208-214.
Reyna-Hurtado, R., Chapman, C.A., Calme, S. \& Pedersen, E. 2012. Searching in heterogeneous environments: foraging strategies in the white-lipped peccary (Tayassu pecari). J. Mammal. 93:124-133.

Ribeiro, J.F. \& Vieira, E.M. 2014. Interactions between a seed-eating neotropical rodent, the Azara's agouti (Dasyprocta azarae), and the Brazilian 'pine' Araucaria angustifolia. Austral Ecol., 39:279-287.

Ribeiro, M.C., Martensen. J.P., Ponzoni, A.C. \&. Hirota, M.M. 2009. The Brazilian Atlantic Forest: how much is left, and how is the remaining forest distributed? Implications for conservation. Biol. Conserv., 142:1141-1153.

Rosa, C.A., Curi, N.H.A., Puertas, F. \& Passamani, M. 2017. Alien terrestrial mammals in Brazil: current status and management. Biol. Invasions, 19(7):2101-2123

Rosa, C.A. 2018. Wild pigs in an irreplaceable area for biodiversity conservation: current situation and importance of the local community in the population control. Modern Management Forum, 2(1):1-7.

Sanguinetti, J. \& Kitzberger, T. 2010. Factors controlling seed predation by rodents and non-native Sus scrofa in Araucaria araucana forests: potential effects on seedling establishment. Biol. Invasions, 12:689-706.

Schupp, E.W. 1988. Factors affecting post-dispersal seed survival in a tropical forest. Oecologia, 76:525-530.

Silman, M.R., Terborgh, J.W. \& Kiltie, R.A. 2003. Population regulation of a dominant rain forest tree by a major seed predator. Ecology, 84(2):431-438.

Solórzano-Filho, J.A. 2001. Demografia, fenologia e ecologia da dispersão de sementes de Araucaria angustifolia em uma população relictual em Campos do Jordão, SP. MSc Dissertation. Universidade de São Paulo, São Paulo.

Souza, A.F., de Matos, D.U, Forgiarini, C. \& Martinez, J. 2010. Seed crop size variation in the dominant South American conifer Araucaria angustifolia. Acta Oecol., 36:126-134.

Srbek-Araujo, A.C. \& Chiarello, A.G. 2013. Influence of camera-trap sampling design on mammal species capture rates and community structures in southeastern Brazil. Biota Neotrop., 13(2):51-62.

Thomas, P. 2013. Araucaria angustifolia. The IUCN Red List of Threatened Species. Version 2015.2. <www.iucnredlist.org>. Downloaded on 26 June 2015.

Ururahy, J.C., Collares, J.E.R., Santos, M.M. \& Barreto, R.A.A. 1983. In RADAMBRASIL, Vegetação, Levantamento dos Recursos Naturais 32, Folhas SF 23/24. Rio de Janeiro/Vitória, Brasil.

Veloso, H.P., Rangel Filho, A.L.R. \& Lima, J.C.A. 1992. Classificação da vegetação brasileira, adaptada a um sistema universal. Instituto Brasileiro de Geografia e Estatística. Rio de Janeiro, Brasil.

Vieira, E.M, Ribeiro, J.F. \& Iob, G. 2011. Seed predation of Araucaria angustifolia (Araucariaceae) by small rodents in two areas with contrasting seed densities in the Brazilian Araucaria forest. J. Nat. Hist., 45(13-14):843-854.

Wang, B.C. \& Smith, T.B. 2012. Closing the seed dispersal loop. Trends Ecol. Evol., 17(8):379-386.

Webber, B., Norton, B.A. \& Woodrow, I.E. 2010. Disturbance affects spatial patterning and stand structure of a tropical rainforest tree. Austral Ecol., 35(1):423-434.

Zuur, A.F., Ieno, E.N., Walker, N.J., Saveliev, A.A.\& Smith, G.M. 2009. Mixed Effects Models and Extensions in Ecology with R. Springer, New York, EUA.

Received: $21 / 08 / 2020$

Revised: 20/10/2020

Accepted: 23/10/2020

Published online: 04/12/2020 